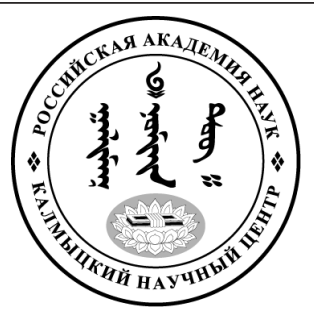

Published in the Russian Federation

Oriental Studies (Previous Name: Bulletin of the Kalmyk Institute

for Humanities of the Russian Academy of Sciences)

Has been issued as a journal since 2008

ISSN: 2619-0990; E-ISSN: 2619-1008

Is. 5 , pp. $787-798,2019$

DOI: $10.22162 / 2619-0990-2019-45-5-787-798$

Journal homepage: https://kigiran.elpub.ru

УДК 93/353.5

\title{
Сальский инцидент, или О том, как донские калмыки не вошли в состав Автономной области трудового калмыцкого народа
}

\author{
Евгений Федорович Кринко ${ }^{1}$ \\ ${ }^{1}$ Калмыцкий научный центр РАН (д. 8, ул. И. К. Илишкина, 358000 Элиста, Российская Федера- \\ ция) \\ доктор исторических наук, ведущий научный сотрудник \\ ORCID: 0000-0003-3008-5626. E-mail: krinkoef@gmail.com
}

Аннотация. Введение. Созданию калмыцкой национальной автономии посвящены многие исследования советских и современных российских историков. Однако некоторые аспекты данной темы до сих пор остаются неизученными. Среди них - судьба донских (сальских) калмыков, не вошедших в состав Автономной области калмыцкого трудового народа в момент ее образования в 1920 г. Целью статьи является поиск ответа на вопрос, почему донские калмыки остались в составе Сальского округа Донской области. Для реализации этой цели были поставлены задачи: выяснить обстоятельства проведения I съезда сальских калмыков и его итоги; описать попытки Калмыцкого ЦИК вернуть сальских калмыков в состав калмыцкой автономии; проанализировать причины неудачи калмыцкого руководства. Материальь и метоdbl. Статья основана на документах фонда Донского областного исполнительного комитета в Государственном архиве Ростовской области. Автор также использовал и другие исторические и историографические источники. В процессе работы с источниками применялись сравнительно-исторический, проблемно-хронологический методы и метод источниковедческой критики. Pезультаты. После Гражданской войны планировалось объединение всех калмыков в одну административно-хозяйственную единицу - Автономную область калмыцкого трудового народа в составе РСФСР. Но вопреки решениям I Общекалмыцкого съезда калмыцкого трудового народа сальские калмыки остались в составе Донской области. Причины этого были связаны с разногласиями внутри новой калмыцкой партийно-государственной элиты, а также противоречиями между Калмыцким ЦИК и Сальским окружным исполкомом. Они свидетельствуют о сложностях взаимодействия различных органов советской власти в первые годы после Гражданской войны. В начале 1920-х гг. многие донские калмыки переселилась в Большедербетовский улус Калмыцкой автономной области. Оставшиеся на Дону калмыки вошли в Зимовниковский (с 1928 г. - Калмыцкий) район Сальского округа Северо-Кавказского края.

Ключевые слова: донские (сальские) калмыки, Донская область, Сальский округ, Калмыцкая автономная область, Калмыцкий ЦИК, Донской областной исполком, национально-государственное строительство

Благодарность. Исследование выполнено в рамках государственной субсидии - проект «Комплексное исследование процессов общественно-политического и культурного развития народов Юга России» (№ г.р. АААА-А19-119011490038-5). Автор выражает признательность директору Государственного архива Ростовской области, к. и. н. Н. А. Трапшу за помощь в предоставлении материалов. 
Для цитирования: Кринко Е. Ф. Сальский инцидент, или О том, как донские калмыки не вошли в состав Автономной области трудового калмыцкого народа. Oriental Studies. 2019;(5): 787-798. DOI: 10.22162/2619-0990-2019-45-5-787-798.

UDC 93/353.5

\title{
The Salsk Incident: or How Autonomous Oblast of the Kalmyk Working People Was Never Joined by the Don Kalmyks
}

\author{
Evgeny F. Krinko ${ }^{1}$ \\ ${ }^{1}$ Kalmyk Scientific Center of the RAS (8, Ilishkin St., Elista 358000, Russian Federation) \\ Dr. Sc. (History), Leading Research Associate \\ ORCID: 0000-0003-3008-5626. Email: krinkoef@gmail.com
}

\begin{abstract}
Introduction. The creation of Kalmyk national autonomy has been examined in many works. However, some its aspects still remain unexplored. Among the latter is the issue of the Don (Salsk) Kalmyks that never joined Kalmyk Autonomous Oblast in 1920, having constituted a community of their own within Don Oblast. Goals and Objectives. . The article seeks to understand why the mentioned group preferred to stay back in Salsk Okrug. To facilitate this, the paper examines the circumstances of the $1^{\text {st }}$ Congress of Salsk Kalmyks and its outcomes; describes attempts of the Kalmyk Central Executive Committee (Rus. $T_{S} I K$ ) to integrate Salsk Kalmyks back into the Kalmyk autonomy; analyzes reasons for the failure of Kalmyk leadership. Materials and Methods. The article analyzes documents of Don Oblast Executive Committee housed by the State Archive of Rostov Oblast. The study also employs other historical and historiographic sources. The investigation of sources involves the use of comparative-historical, problem-chronological, and source criticism methods. Results. Initially, it was planned to unite all Kalmyks into one administrative unit - Autonomous Oblast of the Kalmyk Working People as part of the RSFSR. The $1^{\text {st }}$ All-Kalmyk Congress of the Kalmyk Working People approved this decision, but the Salsk Kalmyks stayed back in Don Oblast. That was caused by disagreements within the new Kalmyk party-and-state elites, as well as by controversies between the Kalmyk TsIK and Salsk Okrug Executive Committee. Those indicate certain travails in the interaction between various Soviet authorities in the aftermath of the Russian Civil War. In the early 1920s, many Don Kalmyks resettled to Bolshederbetovsky Ulus of Kalmyk Autonomous Oblast. The remaining Kalmyks joined Zimovnikovsky District (since 1928 - Kalmytsky District) of Salsk Okrug of NorthCaucasus Krai.

Keywords: Don (Salsk) Kalmyks, Don Oblast, Salsk Okrug, Kalmyk Autonomous Oblast, Kalmyk TsIK, Don Oblast Executive Committee, nation building

Acknowledgments: The reported study was funded by government subsidy — project name 'SocioPolitical and Cultural Development of South Russia's Peoples: a Comprehensive Research of Respective Processes' (state reg. no. AAAA-A19-119011490038-5). The author expresses gratitude to Dr. N. Trapsh, Director of the State Archive of Rostov Oblast, for the provided research materials. For citation: Krinko E. F. The Salsk Incident: or How Autonomous Oblast of the Kalmyk Working People Was Never Joined by the Don Kalmyks. Oriental Studies. 2019;(5): 787-798. DOI: 10.22162/2619-0990-2019-45-5-787-798
\end{abstract}

\section{है}

\section{Введение}

Созданию и дальнейшему становлению калмыцкой национальной автономии посвящен целый ряд серьезных и основательных исследований, среди которых выделяются обобщающий фундаментальный труд по истории Калмыкии [История Калмыкии 2009], работы К. Н. Максимова [Максимов 2002; Максимов 2013; Максимов 2017 и др.], У. Б. Очирова [Очиров 2006; Очиров 2015 и др.], О. В. Северцева [Северцев 2015] и другие публикации [Бадмаева 2010; 
Гунаев 2018; Максимов, Мацакова 2016; Кичеева 2017 и др.]. Они позволяют реконструировать общий ход событий, объяснить логику процессов национального самоопределения калмыцкого народа, выявить их основные тенденции. Немало документов по данной теме опубликовано в специальных сборниках, изданных еще в 1960-1980-х гг. [К истории образования 1960; Первый Общекалмыцкий 1971; Национально-государственное строительство 1981]. Тем не менее отдельные вопросы формирования калмыцкой национальной автономии, в том числе определение ее границ, следует признать недостаточно изученными и требующими дополнительного прояснения с привлечением ранее не использованных источников.

Цель данной работы - на основе комплекса архивных документов выяснить, как и почему донские (сальские) калмыки не вошли в состав Калмыцкой автономной области при ее образовании в 1920 г., а остались в составе Донской области.

\section{Материалы и методы}

Основу источниковой базы статьи составили неопубликованные документы, хранящиеся в Государственном архиве Ростовской области (далее - ГА РО). В фонде Р-97 Донского областного исполнительного комитета (Донисполкома) они составляют специальное дело под названием «Декларация прав калмыцкого трудового народа, принятая первым общекалмыцким съездом Советов, протоколы заседаний съезда калмыков Сальского округа за июль-август 1920 г.» [ГА РО. Ф. Р-97. Оп. 1. Д. 98]. На данные материалы уже обращали свое внимание исследователи, прежде всего К. Н. Максимов, который на их основе охарактеризовал проведение I съезда калмыков Сальского округа и его решения в крупной монографии, посвященной истории донских калмыков [Максимов 2016: 462-463].

Однако название дела не раскрывает всего его содержания. Наряду с указанными декларацией I Общекалмыцкого съезда и протоколами заседаний I съезда калмыков Сальского округа в нем представлены и другие документы, использование которых позволяет проанализировать попытки Калмыцкого ЦИК вернуть сальских калмыков в состав калмыцкой автономии и причины их неудач и другие вопросы. В ходе работы над статьей использовались и другие исторические и историографические источники. В процессе их изучения применялись сравнительно-исторический, проблемно-хронологический методы и метод источниковедческой критики.

\section{Основная часть}

До революции 1917 г. калмыки проживали в границах нескольких административных единиц Российской империи. Общая численность калмыков в России по переписи населения 1897 г. составляла 190,6 тыс. чел. По оценкам У. Б. Очирова, к началу Первой мировой войны она выросла до 195 тыс. чел. [Очиров 2006: 56]. Большинство проживало в 8 улусах Калмыцкой степи, а также в Енотаевском и Черноярском уездах Астраханской губернии: в 1897 г. 138,6 тыс. чел. (72,7 \% общей численности), к 1914 г. - 146 тыс. чел. (74,9\%), не считая нескольких сотен калмыков-казаков Астраханского войска. В Области Войска Донского (в основном в Сальском округе, где они составляли почти половину населения) в 1897 г. насчитывалось 32,3 тыс. (16,9 \% общей численности), к 1914 г. - 31,5 тыс. калмыков (16,2 \%). В Ставропольской губернии (в основном в Большедербетовском улусе) в 1897 г. насчитывалось 10,8 тыс. (5,7 \%), к 1914 г. - 8,5 тыс. калмыков $(4,4$ \%), в Терской области (в основном в Кумском аймаке) - соответственно, 3,6 (1,9\%) и 4,1 тыс. калмыков (2,1\%) [Первая всеобщая; Очиров 2006: 56].

За время Первой мировой и Гражданской войн численность калмыков в России существенно сократилась от потерь в боях, голода и эмиграции. По оценкам У. Б. Очирова, потери калмыков только в годы Гражданской войны составили около 55 тыс. чел. [Очиров 2006: 368]. Значительно уменьшилось и количество донских калмыков, как, впрочем, и всего населения Дона. По данным, приводимым К. Н. Максимовым, в 16 станицах Сальского округа, где в основном проживали калмыки, население с 1917 г. к лету 1920 г. сократилось с 85960 до 56221 человека или на 34,5 \%, а калмыков-казаков — с 27865 до 18529 чел. или на 33,5 \% [Максимов 2016: 461].

Завершение Гражданской войны поставило вопрос о национальном самоопределении калмыцкого народа в наиболее типич- 
ной для первых лет советской власти форме автономии в составе РСФСР. Решение о ее создании должен был провозгласить I Общекалмыцкий съезд калмыцкого трудового народа, проходивший в поселке Чилгир с 2 по 9 июля 1920 г. В его работе приняли участие 349 делегатов, из них 290 с правом решающего и 59 с правом совещательного голоса. 20 делегатов представляли донских калмыков [История Калмыкии 2009: 279]. На съезде была заслушана Декларация прав трудового калмыцкого народа, в которой провозглашалось объединение всех его разрозненных частей в одну административно-хозяйственную единицу - Автономную область калмыцкого трудового народа в составе РСФСР.

Исследователями отмечается, что начало съезда «было омрачено инцидентом». Группа делегатов во главе с активным участником революционного движения, а в годы Гражданской войны - организатором калмыцких военных частей и руководителем их политотдела Х. Б. Кануковым, следуя на съезд через Элисту, избила председателя Манычского улусного исполкома Э. Боданова (Оконова), военкома местного военкомата Реснянского и военрука Аврорского. По прибытии в Чилгир Х. Б. Кануков был арестован и весь съезд провел в заключении. Одного из самых популярных калмыцких военных и политических деятелей даже не избрали в состав облисполкома, что впоследствии «отразилось на взаимоотношениях между Кануковым и рядом калмыцких совработников» [История Калмыкии 2009: 279].

5 августа неожиданно для Калмыцкого ЦИК в станице Великокняжеской (в настоящее время - город Пролетарск) открылся I съезд калмыков Сальского округа, на который прибыли 46 представителей от 12 из 13 донских калмыцких станиц. Не была представлена только станица Эркетиновская, в которой общее собрание калмыков еще 1 августа приняло решение не посылать своих делегатов на съезд, поскольку «граждане вышеназванной станицы желают оставаться в ведении Автономной области трудового калмыцкого народа, согласно Декларации прав калмыцкого трудового народа, принятой I-м общекалмыцким съездом 5-го июля 1920 г.» [ГА РО. Ф. Р-97. Оп. 1. Д. 98. Л. 38].
Сами участники событий считали взаимосвязанными созыв съезда и арест Х. Б. Канукова. Неслучайно главными инициаторами проведения съезда были его соратники по калмыцким военным частям И. Шалхаков, Т. Шивидов и др. Во время открытия съезда И. Шалхаков зачитал два приветственных воззвания - от имени самого Х. Б. Канукова и представителя ВЦИК в Калмыкии К. Р. Герценберга. Очевидцы утверждали, что Х. Б. Кануков в ней «призывал калмыков оставаться в пределах Донской области, не присоединяясь к астраханцам» [ГА РО. Ф. Р-97. Оп. 1. Д. 98. Л. 46об.].

По предложению председателя Сальского окружного исполкома Иванова съезд принял решение направить шесть приветственных телеграмм: председателю СНК РСФСР В. И. Ленину, председателю завершавшего в эти дни работу 2-го конгресca III (Коммунистического) интернационала Г. Е. Зиновьеву, К. Р. Герценбергу, в Реввоенсовет Кавказского фронта, Донскому исполкому и «организатору, военруку калмыцких частей тов. Канукову» [ГА РО. Ф. Р-97. ОП. 1. Д. 98. Л. 15].

Показательно отсутствие в этом перечне Калмыцкого ЦИК, член которого Е. М. Сайков, по его словам, узнал о проведении съезда лишь вечером 4 августа накануне его открытия, «когда уже было поздно посылать на съезд своего представителя» [ГА РО. Ф. Р-97. ОП. 1. Д. 98. Л. 40]. В то же время активную роль на съезде играл Иванов, сам факт присутствия которого вместе с Гуревичем, представлявшим окружной комитет РКП(б), а также их выступления с приветствиями служат прямым подтверждением поддержки, оказанной организаторам органами власти Сальского округа [ГА РО. Ф. Р-97. Оп. 1. Д. 98. Л. 14].

Повестка работы съезда включала несколько вопросов. Важнейший из них об отношении к Калмыцкому областному исполкому - рассматривался 7 августа. В принятой большинством голосов резолюции говорилось: «Мы, делегаты І-го съезда калмыков Сальского округа Донобласти, заявляем: мы, калмыки, проживавшие несколько сот лет в Сальском округе и давно покинувшие кочующую жизнь, признаем, что деление на отдельные автономные области является не рациональным, так как, не разбиваясь на единицы, общими силами мы 
можем скорее победить международную контрреволюцию, легче можем справиться с той хозяйственной разрухой, в которой мы в данный момент находимся, а поэтому входить в административное управление Автономной области Калмыцкого исполкома не желаем, а остаемся по-прежнему гражданами РСФСР, в административном отношении подчиняемся Сальскому округисполкому Донобласти». При этом оговаривалась возможность индивидуального переселения «отдельных калмыков» Сальского округа, которые пожелали перейти в «ведение Автономного областного Калмыцкого исполкома». Это желание не возбранялось, но им предлагалось «выйти из пределов Донобласти в Автономную Калмыцкую область» [ГА РО. Ф. Р-97. Оп. 1. Д. 98. Л. 15об.]. Обращают на себя внимание не только слова о длительности проживания донских калмыков в Сальском округе как историческое обоснование их особого пути («давно покинувшие кочующую жизнь»), но и признание нецелесообразным разделения на автономные области, фактически шедшее вразрез с «генеральной линией» советского руководства в национальном вопросе.

В тесной взаимосвязи с предыдущим рассматривался вопрос о «сгруппировании» всех калмыков 13 станиц в 5 станицах. В принятой большинством голосов резолюции, предложенной Ивановым с поправками Шалхакова, предлагалось: «Выделить комиссию съезда с чрезвычайными правами, которая должна приступить к обследованию пустопорожних помещений» в 5 западных станицах и «приступить к оборудованию таковых».

Комиссия должна была выяснить, «какое количество должно быть переселено, и прикрепить каждого переселяющегося к известной станице». При этом станицы или хутора следовало переселять, «не разрозняя общество». В первую очередь переселению подлежали калмыки, не имевшие посевов, а тех, кто их имел, следовало переселять уже после сбора урожая. Комиссия должна была «позаботиться произвести озимый посев на всех переселяющихся граждан» в 5 западных станицах. Ей поручалось также «ходатайствовать средства для переселяющихся граждан». Съезд просил «высшую инстанцию власти о скорейшем утверждении настоящего постановления» и группировании калмыков в 5 станицах, «желательно переселения в настоящем году, но каждый гражданин должен помнить, чтобы не было брошено на произвол судьбы все, что им засеяно в 1920 году». В примечании подчеркивалось, что все граждане «крестьянского населения», находившиеся в 5 западных станицах, могли оставаться на месте. Прибывавших калмыков-беженцев следовало направлять для регистрации в Чрезвычайную комиссию по переселению калмыков [ГА РО. Ф. Р-97. Оп. 1. Д. 98. Л. 15об.-16].

В завершающий день съезда Шалхаков предложил выделить в окружной исполком двух членов с совещательными голосами. Съезд постановил откомандировать в Сальский окружной исполком Цанкирова и Антипова. Президиум Сальского окружного исполкома одобрил протокол I съезда сальских калмыков и заверил его печатью исполкома [ГА РО. Ф. Р-97. Оп. 1. Д. 98. Л. 16об.].

Однако с решениями съезда, особенно с «группированием» в 5 станиц, согласились далеко не все донские калмыки. После съезда 18 представителей 6 восточных станиц - Бурульской, Власовской, Граббевской (в настоящее время - хутора Бурульский, Власовский, Грабовский Зимовниковского района Ростовской области), Беляевской, Потаповской и Чунусовской (в настоящее время упразднены) подали протест председателю Сальского окружного исполкома Иванову [ГА РО. Ф. Р-97. Оп. 1. Д. 98. Л. 46об.]. По возвращении домой представители станиц рассказывали о решениях І съезда на общих собраниях.

Так, 12 августа собрание калмыков станицы Потаповской, выслушав доклад своих делегатов, постановило «признать для нас неприемлемым» решение преобразовать из 13 калмыцких станиц 5 «с пятью тысячами жителей в каждой из них и с непременным условием теперь же переселить верхние станицы, а именно: Граббевскую, Беляевскую, Бурульскую, Потаповскую и Чунусовскую в юрты низовых станиц». Собрание постановило остаться в Автономной области калмыцкого трудового народа, не переселяясь с мест, «будет возможно или же при невозможности, то уже ближе к Центральному управлению этой области» [ГА РО. Ф. Р-97. Оп. 1. Д. 98. Л. 44].

В тот же день заслушало своих делегатов и общее собрание калмыков станицы Чунусовской. Принимая во внимание, что 
«станица наша в числе других постановлением первого съезда калмыцкого народа на ставке Чилгир 15 июля с. г. присоединена к Автономной области калмыцкого народа», почему вопрос о «сгруппировании» в 5 станицах «с переселением таковых и с подчинением к Донской области нами не приемлем», собрание постановило просить Калмыцкий ЦИК «об утверждении присоединения нашей станицы к Автономной области калмыцкого народа» [ГА РО. Ф. Р-97. Оп. 1. Д. 98. Л. 45].

Через три дня, 15 августа состоялось общее собрание калмыков станицы Беляевской. Делегаты съезда Б. Сесинов и Ф. Джамбинов подчеркнули, что решение о преобразовании 13 калмыцких станиц в 5 утвердили, несмотря на их заявление о нежелании «переселяться и отделяться от Автономной области калмыцкого трудового народа», не принятое во внимание председателем съезда. Собрание подтвердило свое нежелание переселяться и признало неприемлемым постановление I съезда калмыков Сальского округа [ГА РО. Ф.Р-97. ОП. 1. Д. 98. Л. 43].

Решения общих собраний указанных станиц были направлены в Калмыцкий ЦИК, который еще до их получения провел специальный пленум 16 августа. Главным в его повестке был вопрос «Об отношении калмыков Сальского округа Донской области к постановлению Первого Общекалмыцкого съезда Советов по объединению калмыков в одну автономную область». Выступивший на пленуме А. М. Амур-Санан обратил внимание «на полную безграмотность» резолюции съезда, считая, что сам его созыв без приглашения представителя Калмыцкого ЦИК является «продуктом агитации отдельных лиц, идущей в разрез интересам объединения трудовых калмыков и в нарушение их автономных прав». Как и выступавший после него военком А. Г. Маслов, он связал резолюцию о нежелании калмыков-донцов входить в состав Автономной области калмыцкого трудового народа с арестом Канукова, «по происхождению донца, учинившего дебош накануне Первого общекалмыцкого съезда, который он вместе с эскадроном шел охранять и на который он был делегирован в числе других 20 представителей калмыков Сальского округа». В подтверждение недобросовестности агитации и давления на съезд Шалхакова и
Шивидова, заставивших донских калмыков «отказаться от объединения со своими сородичами», Амур-Санан и Маслов зачитали выдержки из письма политического комиссара Калмыцкого полка Бузутова. В нем указывалось на распространение между красноармейцами Калмыцкого полка слухов «о недолговечности областного исполкома», а также о том, что «астраханские главари Маслов, Чапчаев, Маслова, Амур-Санан» и другие «ненавидят донцов, воображая себя царями» [ГА РО. Ф. Р-97. Оп. 1. Д. 98. Л. 39об.-40].

Протокол дает некоторое представление о накале страстей в ходе заседания пленума. Амур-Санан и Маслов предложили «произвести расследование всех обстоятельств, послуживших причиною этого неприятного инцидента и предать суду всех вообще оказавшихся виновными в подрыве авторитета советской власти, как с той, так и с другой стороны». Был задан вопрос члену областного исполкома Герценбергу о приветственном воззвании съезду и ответной приветственной телеграмме, выслушаны делегаты-донцы. Амур-Санан поднял и вопросы о значении принятой I Общекалмыцким съездом Декларации об автономии объединившихся калмыков, а также о том, «следует ли вообще ехать в центр домогаться утверждения всех работ съезда» [ГА РО. Ф. Р-97. Оп. 1. Д. 98. Л. 39об.-41].

Однако секретарь облисполкома Ф. И. Плюнов, имевший большой опыт еще дореволюционной работы в органах управления, обратил внимание на то, что на I Общекалмыцком съезде Советов присутствовали делегаты Советов всех улусов, включая и представителей донских калмыков. Они принимали активное участие в решении съездом всех вопросов, в том числе о принятии декларации, а также в выбоpe членов областного исполкома. Представитель донцов сделал доклад о положении калмыков Донской области, а ряд депутатов (в том числе Шивидов) выступали с приветственными речами. Поэтому Плюнов заявил, что «никаких сомнений в юридической силе декларации быть не может», I Общекалмыцкий съезд Советов «является для калмыков органом законодательным, и постановления его имеют силу и значение юридического акта. Нет никаких оснований ожидать разрешения частичного харак- 
тера инцидентов, тем более, направленных во вред объединения калмыков и признания за ними автономных прав» [ГА РО. Ф. Р-97. Оп. 1. Д. 98. Л. 41-41об.].

В итоге пленум постановил послать на Дон комиссию из трех лиц, в которую вошли член областного исполкома У. Д. Душан, член исполкома Большедербетовского улусного комитета Л. К. Карвенов и член президиума Калмыцкого ЦИК Е. М. Сайков, поручив ей созвать новый съезд Советов калмыков Сальского округа и «произвести по всем обстоятельствам настоящего инцидента и причинах, вызвавших его, расследование, которое и представить облисполкому». После выступления Ф. И. Плюнова пленум постановил немедленно представить центру на утверждение Декларацию трудового калмыцкого народа, делегировав в Москву с трудами съезда А. Амур-Санана и И. Мангинова [ГА РО. Ф. Р-97. Оп. 1. Д. 98. Л. 41-41об.].

23 августа состоялся новый пленум ЦИК Автономной области калмыцкого трудового народа, на котором Е. М. Сайков выступил с докладом «по ходатайству обществ станиц Потаповской, Эркетиновской, Чунусовской и Беляевской Донской области об отказе их подчиниться постановлению съезда Советов Сальского округа от 5 августа и о желании остаться в составе Автономной области калмыцкого народа» [ГА РО. Ф. Р-97. Оп. 1. Д. 98. Л. 46]. Представители Эркетиновской, Чунусовской и Беляевской станиц рассказали, что после I Общекалмыцкого съезда к ним приезжал Мангушев, настаивавший на том, чтобы представители станиц обязательно прибыли на съезд. Когда же раздались протесты, он «угрожал прислать в станицу карательный отряд с пулеметом, причем даже записал 10 граждан, особенно протестующих против насилия, пригрозив им, что они будут расстреляны. Под страхом угроз пришлось представителям станиц выехать на съезд, но так никаких протестов не допускалось и никаких заявлений не принималось, съезд прошел под сильным давлением военной партии, причем особенно настойчиво агитировал Шалхаков, который указывал, что нет никакого интереса объединяться с астраханцами, в особенности после того, как арестован Кануков» [ГА РО. Ф. Р-97. Оп. 1. Д. 98. Л. 4646об.].
Через неделю, 30 августа, члены комиссии Калмыцкого ЦИК обратились с заявлением в Сальский окружной исполком, в котором утверждали, что «президиум съезда сальских калмыков при ведении заседания в некоторых принятых съездом резолюциях допустил нарушение закона РСФСР». Основные нарушения сводились к четырем основным пунктам.

Во-первых, резолюция о выселении не желавших «подчиниться Донобласти» в Автономную область трудовых калмыков, по их мнению, явно противоречила принципу советской власти о свободном проживании всех граждан «безотносительно к национальности, вере и приписке там, где граждане найдут нужным и необходимым». Насильственное выселение расценивалось как «явный акт насилия, совершенно нетерпимый по советским законам». Члены комиссии писали, что «многие темные калмыки, не знающие советских законов, боясь выселения в Автономную область трудовых калмыков, конечно, откажутся от идеи вхождения» в нее [ГА РО. Ф. Р-97. Оп. 1. Д. 98. Л. 47].

Во-вторых, резолюция о нерациональном разделении на автономные области признавалась противоречащей пунктам 2, 8, 11 Конституции РСФСР, «коим всем национальностям даны права на национальность и самоопределение вплоть до отложения и образования самостоятельных автономных областей, республик и пр.».

B-третьих, крупной ошибкой I съезда сальских калмыков называлось «неизбрание на съезде, если они признают Донобласть», полноправных членов в Совет окружного исполкома, а участие двух представителей от калмыков с совещательным голосом в его работе считалось «совершенно не законным» [ГА РО. Ф. Р-97. Оп. 1. Д. 98. Л. 47-47об.].

В-четвертых, члены комиссии писали, что «съездом не обсужден вопрос о создании объединения с русскими станичных исполкомов или о создании национальных калмыцких исполкомов».

Кроме того, они отмечали, что на І съезде сальских калмыков были допущены еще несколько «мелких, но характерных его ошибок». 1. Председателем съезда Шалхаковым иногда удалялись с заседания агитаторы политотдела калмыцких военных частей Бембеев, Долотаев, Манджиев и Яшкаев, «т. е. 
заседания иногда велись конспиративно, секретно». Члены комиссии подчеркивали: «Удаления из заседания агитаторов-коммунистов - прямое нарушение закона». 2. Не было принято заявление группы членов съезда «о верности Автономной области калмыцкого трудового народа». 3. В Калмыцкий ЦИК в Астрахань прибыли представители трех станиц с постановлениями станиц Эркетиновской, Чунусовской, Потаповской и Беляевской о том, что они не признают резолюций, постановлений съезда калмыков Сальского округа и остаются верными постановлениям I Общекалмыцкого съезда Советов, т. е. входят в Автономную область трудовых калмыков.

Члены комиссии подчеркивали необходимость срочно разъяснить населению эти «упущения и незаконные резолюции съезда донских калмыков», а также просили Сальский окружной исполком о срочном созыве нового съезда сальских калмыков. На нем должны были быть исправлены все допущенные нарушения законов РСФСР и выяснен вопрос «о вхождении или невхождении сальских калмыков» в Автономную область трудовых калмыков [ГА РО. Ф. Р-97. Оп. 1. Д. 98. Л. 47об.-48].

На следующий день в станице Великокняжеской состоялось заседание президиума Сальского окружного исполкома совместно с членами комиссии ЦИК Автономной области калмыцкого трудового народа, а также с бывшим членом президиума сальского съезда калмыков Шалхаковым. Он и давал ответ на два первых пункта заявления членов комиссии, признав утвержденные I съездом формулировки «редакционными ошибками». Текст резолюции «Должны выйти из пределов Донобласти в Автономную Калмыцкую область», по словам Шалхакова, следовало понимать, как «выйти из пределов Донобласти в административном отношении». По второму пункту заявления он сказал, что «так угодно было съезду калмыков высказаться», признав деление на автономные области не рациональным, потому что существовавший с 1918 г. Калмыцкий облисполком «не принимал никаких мер к объединению калмыков и оказанию помощи». Шалхаков заявил, что текст резолюции следует понимать не как «нерациональное деление на автономные области», а как «нерациональное присое- динение сальских калмыков к автономной области» [ГА РО. Ф. Р-97. Оп. 1. Д. 98. Л. 50-50об.].

По третьему и четвертому пунктам выступали члены окружного исполкома Буревалов и Гуреев, заявившие, что калмыки Сальского округа участвовали в выборах Советов «вообще с русскими», а в станичных исполкомах есть члены-калмыки. 2 члена с совещательным голосом были введены съездом в окружной исполком «для живой связи с калмыками». Гуреев также подчеркнул, что представительства на правах национальных меньшинств не было, так как выборы в Советы, на съезды Советов и в исполкомы происходили в округе без различия на национальности и только потому, «что калмыки недавно вернулись из стана Деникина и еще не освободились» [ГА РО. Ф. Р-97. Оп. 1. Д. 98. Л. 50об.-51].

Шалхаков назвал ложью удаление со съезда калмыцких агитаторов, более того, агитаторы Долотаев, Манджиев и Яшкаев, по его словам, не являлись коммунистами. Буревалов подчеркнул, что присутствовавший на съезде Иванов не допустил бы «ни в коем случае, чтобы производились какие-либо секретные совещания и в особенности без коммунистов-агитаторов». В результате уже Сайкову пришлось оправдываться, признав, что «все мелкие недочеты, помещенные ими в заявлении, взяты со слов некоторых калмыков». Гуреев также указал, что съезд калмыков созывался с разрешения окружного исполкома, всем калмыцким станицам и хуторам предварительно рассылалась повестка дня, и, отправляя своих представителей на съезд, «калмыки знали, кого посылали и, следовательно, эти станицы должны подчиниться, и играться в этом случае нельзя» [ГА РО. Ф. Р-97. Оп. 1. Д. 98. Л. 51-51об.].

В результате членам комиссии было, фактически, отказано по всем пунктам их требований. Президиум Сальского окружного исполкома признал правомочным I съезд сальских калмыков, как созванный с «соответствующим желанием» и с надлежащего разрешения, постановления которого были утверждены самим окружным исполкомом и отделом управления Донисполкома. Нарушения законов РСФСР, которые выступали главным аргументом у членов комиссии, были признаны редак- 
ционными ошибками. Но президиум заявил, что «разрешить второго съезда не может» и, кроме того, констатировал, что также не был извещен о I Общекалмыцком съезде в Астраханской губернии, поэтому счел «представительство от сальских калмыков пропорционально астраханским и ставропольским калмыкам неправильным» [ГА РО. Ф. Р-97. Оп. 1. Д. 98. Л. 50-51об.].

Членам комиссии ничего не оставалось делать, кроме как зафиксировать свое особое мнение. Они также признали редакционные ошибки, противоречащие законам РСФСР, допущенные съездом сальских калмыков, но посчитали необходимым исправить их на следующем съезде сальских калмыков. «Волю четырех станиц» - Эркетиновской, Потаповской, Беляевской и Чунусовской - об их присоединении к ЦИК Автономной области калмыцкого трудового народа — члены комиссии сочли законной, заявив необходимым «произвести реорганизацию власти, порученную ЦИК калмыцкого народа, с выделением этих станиц из ведения Донобласти» [ГА РО. Ф. Р-97. ОП. 1. Д. 98. Л. 52].

Мнение Сальского окружного исполкома о нежелании считаться с волей этих станиц комиссия нашла противоречащим постановлению РСФСР и постановлению самого съезда сальских калмыков, вынесенному 7 августа. Непризнание Сальским окружным исполкомом прав калмыков как национального меньшинства, т. е. их прав на национальное самоопределение, комиссия также сочла противоречащим основным законам РСФСР. Члены комиссии отметили, что поставят об этом в известность Доноблисполком, ЦИК Автономной области калмыцкого трудового народа и Калмыцкий отдел при Наркомате по делам национальностей. Для дальнейшего выяснения этих вопросов в Доноблисполком был направлен Е. М. Сайков [ГА РО. Ф. Р-97. Оп. 1. Д. 98. Л. 52-52об.].

4 сентября Сайков обратился в Донской облисполком, предоставив для выяснения всех обстоятельств дела необходимый пакет документов (благодаря чему он и отложился в фонде Р-98 ГА РО). В заявлении он просил «разрешить созыв нового съезда сальских калмыков» комиссии ЦИК Автономной области калмыцкого трудового народа совместно с президиумом Сальско- го окружного исполкома [ГА РО. Ф. Р-97. Оп. 1. Д. 98. Л. 30-31об.].

Однако отменить принятое на I съезде сальских калмыков решение и вернуть их в состав Автономной области калмыцкого трудового народа ее руководству так и не удалось. На II съезде калмыков Сальского округа оно вновь прошло, теперь уже с перевесом всего в один голос [Очиров 2006: 353]. И, хотя итоги данного голосования также оспаривались, территория проживания сальских калмыков осталась в составе Донской области.

Осенью решение о предоставлении калмыкам автономии получило поддержку высших государственных и партийных органов страны. 14 октября 1920 г. постановление ЦК РКП(б) «О задачах РКП(б) в местностях, населенных восточными народами» признало необходимым создать автономию для тех восточных народностей, которые еще не имели автономных учреждений, прежде всего для калмыков и бурят-монголов. 2 ноября СНК РСФСР постановил предоставить автономию калмыкам [Декреты Советской 1983: 364]. 4 ноября было принято совместное постановление ВЦИК и СНК РСФСР, в котором первым пунктом говорилось: «Образовать автономную область калмыцкого народа». Установление границ и выработка положения об автономной области поручались комиссии в составе представителей наркоматов по делам национальностей, внутренних дел и земледелия РСФСР «с участием представителей заинтересованной национальности и заинтересованных губисполкомов», которая обязывалась закончить работу в кратчайший срок [Декреты Советской 1983: 167]. 25 ноября было издано специальное постановление ВЦИК и СНК РСФСР о границах Автономной области калмыцкого народа. Сальских калмыков в ее составе не оказалось [Декреты Coветской 1983: 262].

\section{Выводы}

На установление границ первых советских автономий оказывали влияние самые различные политические, экономические и другие факторы. Нередко их формирование сопровождалось ожесточенными спорами между руководством разных национальных автономий, в разрешение которых приходилось вмешиваться центральной власти. 
Чрезвычайно затрудняла проведение административных границ в строгом соответствии с национальным принципом существовавшая во многих регионах страны этническая чересполосица. В этом отношении формирование границ Калмыцкой АО в момент ее образования представляет собой особый случай в практике советского национально-государственного строительства. Сокращение первоначально запланированной и предварительно согласованной с центром территории было обусловлено здесь не противоречиями с другими национальными и административными субъектами, а совершенно другими причинами преимущественно внутреннего характера.

Арест крупного военного и политического деятеля периода Гражданской войны и донского калмыка по происхождению Х. Б. Канукова фактически в момент провозглашения автономии с последовавшим отстранением из руководящего органа вызвали недовольство его сторонников. Заручившись поддержкой региональных властей, в первую очередь, что вполне объяснимо, руководства Сальского округа, лишавшегося в случае передачи Калмыкии 13 станиц значительной части своих территорий и населения, они провели I съезд донских калмыков, принявший решение выйти из-под контроля Калмыцкого ЦИК.

В то же время будет упрощением сводить весь вопрос к последствиям инцидента с участием Канукова, тем более что сами пострадавшие вскоре его простили. В том, что автономия лишилась части территории, на которую вполне могла рассчитывать при других обстоятельствах, сказались, по крайней мере, несколько факторов, требующих дополнительного изучения. Во-первых, это разногласия внутри формирующейся новой калмыцкой партийно-государственной элиты (показательно, что организаторы съезда сальских калмыков обвиняли руководителей автономии в стремлении «вообразить себя царями»), что побуждает более внимательно анализировать ее состав, наличие отдельных группировок и причины их образования. Во-вторых, плохо скрываемые разногласия между Калмыцким ЦИК и Сальским окружным исполкомом (вероятно, обоюдные, неслучайно члены президиума окружного исполкома указывали на то, что не были поставлены в известность о
I Общекалмыцком съезде), свидетельствующие о сложностях взаимодействия различных органов советской власти в целом и их конкуренции между собой.

К сожалению, рассмотренный комплекс документов не позволяет глубоко проанализировать позицию руководства Донисполкома и центрального советского руководства по данному вопросу. Не дает он возможности услышать и непосредственные голоса рядовых станичников-калмыков, от лица которых принимались решения, за исключением представителей станиц, протестовавших против решений I съезда сальских калмыков. В данной связи необходимо сказать, что в начале 1920-х гг. значительная часть донских калмыков переселилась в Большедербетовский улус Калмыцкой автономной области. Однако причины этих миграций могли быть вызваны не только стремлением жить в единой автономии, но и низким уровнем жизни, голодом и нищетой в условиях перехода от военного коммунизма к нэпу. Неслучайно на I съезде сальских калмыков представители и тех станиц, которые выступили против его решений, и тех, которые проголосовали за них, говорили о крайней нужде населения «в продовольствии, обуви и одежде, жилых помещений, которые во время Гражданской войны часть разрушены совсем, а большинство не имеет ни окон, ни дверей, ни печей, сельскохозяйственного живого и мертвого инвентаря, кроме того некоторыми докладчиками были указаны на ненормальные явления в районах их места жительства». Например, представитель Граббевской станицы «указал на неправильное распределение продуктов между калмыцким и русским населением. Так, калмыцкое население получало 15 фунтов на едока в месяц, русское же по одному пуду на едока на тот же месяц» [ГА РО. Ф. Р-97. Оп. 1. Д. 98. Л. 15]. Очевидно, что в этой ситуации этническая мобилизация выступала способом решения социальных проблем. Но, вероятно, по той же самой причине, уже с 1924 г. началась обратная миграция калмыков на Дон.

Оставшиеся на Дону калмыки были причислены к Зимовниковскому, с 1928 г. Калмыцкому району Сальского округа Северо-Кавказского края. 29 апреля 1929 г. было принято решение об образовании Калмыцкого национального района в составе 
Сальского округа Северо-Кавказского края, с 1937 г. — в составе Ростовской области. Он просуществовал вплоть до 1944 г. и был упразднен в связи с депортацией калмыков на восток страны.

\section{Источники}

\section{Архивные источники}

ГА РО - Государственный архив Ростовской области

\section{Сборники документов}

Декреты Советской 1983 - Декреты Советской власти. Т. ХІ. Октябрь-ноябрь 1920 г. М.: Политиздат, 1983. 467 с.

К истории образования 1960 - К истории образования автономной области калмыцкого народа (октябрь 1917 - ноябрь 1920 гг.): сб. док-тов и мат-лов. Элиста: Калмиздат, 1960. $104 \mathrm{c}$.

Национально-государственное строительство 1981 - Национально-государственное строительство в Калмыцкой АССР (июль 1920 - июнь 1937 гг.): сб. док-тов и мат-лов. Элиста: Калмыцкое кн. изд-во, 1981. 367 с.

Первый Общекалмыцкий 1971 - Первый Общекалмыцкий съезд советов. 2-9 июля 1920 г. Протоколы. Элиста: КНИИЯЛИ, 1971. 219 с.

\section{Статистические материаль}

Первая всеобщая - Первая всеобщая перепись населения Российской империи 1897 г. Распределение населения по родному языку, губерниям и областям [электронный ресурс] // URL: http://www.demoscope.ru/weekly/ssp/ rus_lan_97.php (дата обращения: 4.04.2019).

\section{Archives}

\section{Sources}

State Archive of Rostov Oblast

\section{Collections of Documents}

[1 ${ }^{\text {st }}$ All-Kalmyk Congress of Soviets: July 2-9, 1920. Minutes of Meetings]. Elista: Kalmyk Research Institute of Language, Literature and History, 1971. 219 p. (In Russ.)

[Autonomous Region of the Kalmyk People: History of Its Creation Revisited (October 1917 November 1920)]. Coll. documents and materials. Elista: Kalmizdat, 1960.104 p. (In Russ.)

[Decrees of the Soviet Government]. Vol. XI: October-November 1920, Moscow: Politizdat, 1983.467 p. (In Russ.)

[Nation Building in the Kalmyk ASSR: July 1920 June 1937]. Coll. documents and materials. Elista: Kalmyk Book Publ., 1981. 367 p. (In Russ.)

\section{Statistical Materials}

$\left[1^{\text {st }}\right.$ Russian Imperial Census of 1897: Distribution of the Population by Mother Tongue, Governorates and Oblasts]. An Internet resource: http://www. demoscope.ru/weekly/ssp/rus_lan_97.php (accessed: April 4, 2019). (In Russ.)

\section{Литература}

Бадмаева 2010 - Бадмаева С. Г. Развитие административно-территориального устройства Калмыкии: 1920-1941 гг. Дисс ... канд. ист. наук. Элиста, 2010. 230 с.

Гунаев 2018 - Гунаев E. A. Акты конституционного значения в системе управления Калмыцкой автономной области (1920-1935 гг.) // Монголоведение. 2018. № 5. С. 50-66.

История Калмыкии 2009 - История Калмыкии с древнейших времен до наших дней. В 3 т. Элиста: Издат. дом «Герел», 2009. Т. 2. $840 \mathrm{c}$.

Кичеева 2017 - Кичеева М. И. Создание национальной государственности Калмыкии в форме автономной области // Ежегодные научные чтения Калмыцкого научного центра Российской академии наук - VI. Элиста: КалмНЦ РАН, 2017. С. 48-50.

Максимов 2002 - Максимов К. Н. Калмыкия в национальной политике, системе власти и управления России (XVII-XX в.). М.: Наука, $2002.523 \mathrm{c}$.

Максимов 2013 - Максимов К. Н. Калмыкия в советскую эпоху: политика и реалии. Элиста: Издат. дом «Герел», 2013. 464 с.

Максимов 2016 - Максимов К. Н. Калмыки в составе донского казачества (XVII - середина ХХ в.). Ростов-на-Дону: Изд-во ЮНЦ PAH, 2016. $576 \mathrm{c}$.

Максимов 2017 - Максимов К. Н. Альтернативы в строительстве национальной государственности XX в. и значение их в исторической судьбе калмыцкого народа // Magna Adsurgit: Historia Studiorum. 2017. № 1. C. 64-73.

Максимов, Мацакова 2016 - Максимов К. Н., Мацакова М. И. Конституирование национальной государственности Калмыкии в форме административной автономии // Вестник Калмыцкого института гуманитарных исследований РАН. 2016. № 3. С. 11-19.

Очиров 2006 - Очиров У. Б. Калмыкия в период Гражданской войны (1917-1920 гг.). Элиста: НПП Джангар», 2006. 448 с.

Очиров 2015 - Очиров У. Б. Правоохранительные и судебные органы Калмыкии в 19171925 гг. // Вестник Калмыцкого института гуманитарных исследований РАН. 2015. № 4. C. 34-42. 
Северцев 2015 - Севериев О. В. Национальное самоопределение. Элиста: Изд-во ИКИАТ, 2015. 252 c.

\section{References}

[History of Kalmykia: from the Earliest Times to the Present Days]. In 3 vols. Elista: Gerel, 2009. Vol. 2. 840 p. (In Russ.)

Badmaeva S. G. [Development of Kalmykia's Administrative and Territorial Framework: 1920-1941]. A Cand.Sc. thesis. Elista, 2010. 230 p. (In Russ.)

Gunaev E. A. The administrative system of Kalmyk Autonomous Oblast (1920-1935): acts of constitutional significance. Mongolian Studies. 2018. No. 5. Pp. 50-66. (In Russ.)

Kicheeva M. I. Establishing Kalmykia's national autonomy in the form of an autonomous oblast. In: [Kalmyk Scientific Center of the RAS: Annual Scholarly Readings - VI]. Elista: Kalmyk Scientific Center of RAS, 2017. Pp. 48-50. (In Russ.)

Maksimov K. N. [Kalmykia in the Soviet Era: Policies and Realia]. Elista: Gerel, 2013. 464 p. (In Russ.)

Maksimov K. N. [Kalmyks within the Don Cossack Host: $17^{\text {th }}-$ mid-20 ${ }^{\text {th }}$ Centuries]. Rostov-on-
Don: Southern Scientific Center of RAS, 2016. 576 p. (In Russ.)

Maksimov K. N. Alternatives of the $20^{\text {th }}$-century nation building and their historical significance for the Kalmyk people. In: [Magna Adsurgit: Historia Studiorum]. 2017. Vol. 1. Pp. 64-73. (In Russ.)

Maksimov K. N. Kalmykia in Russia's Past and Present National Policies and Administrative System. Moscow: Nauka, 2002. 523 p. (In Russ.)

Maksimov K. N., Matsakova M. I. The establishment of the constitution of the national state of Kalmykia in the form of administrative autonomy. Bulletin of the Kalmyk Institute for Humanities of the RAS (Oriental Studies). 2016. No. 3. Pp. 11-19. (In Russ.)

Ochirov U. B. [Kalmykia during the Russian Civil War: 1917-1920]. Elista: Dzhangar, 2006. 448 p. (In Russ.)

Ochirov U. B. Law-enforcement and judicial authorities of Kalmykia in 1917-1925. Bulletin of the Kalmyk Institute for Humanities of the RAS (Oriental Studies). 2015. No. 4. Pp. 34-42. (In Russ.)

Severtsev O. V. [National Self-Determination]. Elista: IKIAT, 2015. 252 p. (In Russ.) 